\title{
The Word 'Noor': Tracing a Long Journey through Translation and Adaptation from Classical Arabic to Contemporary Punjabi/Hindi Pop Songs
}

\author{
Azhar Uddin Sahaji \\ Assistant Professor (ad hoc), Department of English, Zakir Husain Delhi College (M), \\ University of Delhi. ORCID id: oooo-ooo1-8675-4716. Email:info.azharsahaji@gmail.com
}

\begin{abstract}
In contemporary India, through popular Punjabi, Bollywood songs, we often come across the word "Noor" (tere chehre ka noor etc.) in reference to a female beauty most of the times. We have become so familiar with the word that we almost forgot that the Arabic original word gained its immortal significance when it is mentioned in the Quran in association with the God. The exact and a fixed meaning of the of word "Noor" is not given in the Quran and perhaps, that gives an opportunity which enabled the word to travel worldwide in different languages with different significance attached to it, from spiritual Sufi literature to sensational pop music. This paper will attempt to show how the word Noor has been translated, transliterated, adopted not just literally but the spiritual and religious significances attached to it. This paper will argue that the word Noor itself has not gone through so much of translation apart from transliteration but the significance associated with it have gone through tremendous translations in different languages and cultures. The paper will also argue that the journey of the word through different linguistic and cultural spheres have lost some of its significance as well gained significances through the process of translation.
\end{abstract}

Keywords: Noor, Translation, Adaptation, Arabic, Persian, Vernacular languages, Punjabi/Hindi Pop Songs

\section{Introduction}

Translation exists because men speak different languages"

George Steiner, After Babel (1975) p.491

"As this world shrinks together like an ageing orange and all the people in all cultures move closer together (however reluctantly and suspiciously ) it may be that the crucial sentence for our remaining years on earth may be very simply:

TRANSLATE OR DIE."

Eagle and Eagle, Contemporary Translation Theories (1985) p.2.

No doubt, translation as a literary work of art has its own significance in the contemporary world. Without translation, perhaps our existence would have been more difficult in the times of globalization. Translation studies have been included in courses in humanities and it seeks to address various issues that arise during the task of translation. Adaptation is another important work of art which is also seen as a part of translation work, though in a different form known as

(C) AesthetixMS 2021. This Open Access article is published under a Creative Commons Attribution Non-Commercial 4.0 International License (http://creativecommons.org/licenses/by-nc/4.o/), which permits non-commercial re-use, distribution, and reproduction in any medium, provided the original work is properly cited. For citation use the DOI. For commercial re-use, please contact editor@rupkatha.com. 
inter-semiotic translation. Adaptation of literary texts into films or vice versa could be cited as an example. Although adaptation is also seen as a separate work of art and is not seen in association with translation. While the relation between translation and adaptation have been well addressed by the scholars of translation and adaptation, there are a few issues which raise more concerns to the existing body of scholarly research and the Noor ${ }^{i}$ could be counted as one of them. In contemporary (and popular) Punjabi and Bollywood songs the word noor can be heard very often. It is used in reference to female beauty, beloved and so on. But the word actually comes from the Arabic language which in turn originates from the Proto-Semitic word $و$ و ن (n-w-r) meaning the Light of God, fierce, fiery and some such related words. The word has a long history of travel through (old) Aramaic, Hebrew and Arabic down to many languages all across the world. In general, the meaning of the word noor in modern Arabic, Hebrew and in the Indian Bhasha (Vernacular) languages like Urdu, Hindi, Sindhi, Bangla, Kashmiri, Punjabi and others more or less are same--'light', 'enlightenment' 'dazzling beauty' 'beauty', 'shine', 'shining beauty', 'bright' and many more related words. iii The objective of this paper is not to focus upon or discuss the theosophical or religious significance of the word Noor in Islam or in any of the Biblical texts but to show how the word, which carries so much deep of philosophical and theosophical significances with it is now used in completely contrary contexts in contemporary popular Punjabi and Hindi songs. This paper will first lay down the etymological history and theosophical significances attached to it in classical Hebrew, Aramaic, (classical) Arabic languages; Islamic and Sufi literature and then the paper will move on to argue that how the word appears to have a complete change of the significances attached to it---from deep theosophical to mundane beauty. Further, the paper will move on to argue that the word attained its momentum in terms of theosophical and religious significance after its usage in the Islamic sacred texts and thereafter, particularly in the Quran. Thus the paper will move on to argue that the word Noor itself has not gone through translation as such apart from transliteration but the significances associated with it has gone through tremendous translations in different languages and cultures. The paper will also argue that the journey of the word through different linguistic and cultural spheres have lost some of its significances as well as gained in the same way. In this particular case of the word Noor, it stands between translation and adaptation, leaving it to multiple interpretations in different contexts and problematizing the existing theories of translation and adaption.

In this particular context, we see a localization of the significance of the word in different contexts. It is a curious case of a word in translation/adaptation demands to be addressed from a completely new theoretical perspective. It is not a novel or poetry or a document which poses a particular set of problems to translators such as questions of cultural equivalence, Target Language, Source Language, localization of translation etc. Moreover, the word and significance attached to it must be looked at through the perspective of Loss and Gain in translation as Susan Bassnett in her book Translation Studies (2002). Further, the context of a word in a text or a Text itself has to be understood in translation studies. A text and the words it contains have many levels of significance---cultural, linguistic, religious, philosophical and so on. Therefore, when a word or a text is translated into Target Language it is replaced with another word. Such an act could, of course, be called a translation but it will certainly lose the significance of the context that it had in the Source Language and the paper argues in its very outset that, the travel and adaptation of the word were only possible when it was loaded with high religious and theosophical significances. Otherwise, apart from Noor words like Musafir, safr, hum-safr, habibi and so many Arabic words have been incorporated to Vernacular languages and they are also very frequently used in literature, music in South Asia. But they perhaps, they do not carry loaded significances as a word in different contexts as the word Noor does ${ }^{\text {iv }}$. In this respect, Lawrence Venuti very aptly observes: 
"A translation recontextuaizes the source text by creating a receiving intertext that replaces relations to the source literature with relations to literary traditions in the receiving culture, so that the reader of the translation must possess the literary and cultural knowledge to perceive the intertext as well as the critical competence to formulate its significance for both the source as well as the translated text." (Venuti 209)

But in this particular case of the word Noor the above proposition of Venuti is problematic owing to the limitation of the text is just a word. Then it raises some evident questions: Is the word Noor 'recontextualized' are Venuti argues? Is translation/adaptation of the word Noor is a conscious act? Could the translation/adaptation of the word Noor be understood in the light of the opinion Venuti has proposed?

\section{Noor in the Old and New Testament}

In the Book of Daniel in the original Aramaic version of the Old Testament, the word Noor is specifically mentioned in reference to a blazing fire. In 3:6v the word "פוּר" transliterated as "nur" (and phonetic spelling is "noor") interestingly is the same as we use in modern Arabic and Indian vernacular languages. The word is used about the story of three Jews and their encounter with the cruel king Nebuchazznezzar who threatens to throw them all in a blazing fire if they refuse to worship him. Here the word/s 'fire' or 'blazing fire' is translated from Hebrew word "פָּר "with an Aramaic origin "from a root corresponding to the source of "ner" defining "a fire"vi. The New American Standard Bible translated the word as "of a furnace of blazing fire ${ }^{\mathrm{vii}}$." King James Version of the Bible translates it as "of a burning fiery furnace"; and the Biblos Interlinear Bible translated it as "the mist of a furnace fire of blazing"viii. Further, in the Hebrew Bible, the word is referred as "אור" "'ór" and in the original Aramaic text, it is referred as "” which in the Greek nuhrā" "ix "rima Bible $^{\mathrm{x}}$ is translated as "Light" where Jesus says, "Then spake Jesus again unto them, saying, I am the light of the world: he that followeth me shall not walk in darkness, but shall have the light of life" (John 8:12). Thus we can see the word noor has a Proto-sematic origin, developed from 'fire' or 'blazing fire' in the old Hebrew/Aramaic testament to the Light of the Jesus or enlightenment in the New Testament ${ }^{\mathrm{xi}}$. Here it must not be assumed that the word actually travelled from Old Hebrew to Aramaic to Arabic and then to modern Vernacular (and world) languages. Since Protosemitic is a hypothetically constructed language Old/Modern ${ }^{\mathrm{xii}}$ Hebrew, (Aramaic, being a dialect of many branches of Old Hebrew language) and Old/Modern Arabic are sister ${ }^{\text {xiii }}$ languages. They did not derive from each other, although adaptation, interchange and loaning of words have always been there $\mathrm{x}^{\mathrm{xiv}}$. Thus in the course of the paper, this paper will also argue that the usage and reception of the word Noor in Indian vernacular and modern world languages happened directly from Arabic, not from Hebrew or Aramaic.

\section{Noor in the Quran and Islamic Literature}

Since Arabic is one of the Sematic languages, it should not be surprising for us if we see a complete similarity between Biblical and Qur'anic word noor. In the very first verse of chapter no. 24 "AlNur" "The Light", the book Quran itself is referred to as Noor or guidance---to enlightenment and truth. The verse reads: "This is a chapter which We have revealed and which we have made obligatory; We have sent down clear revelations in it so that you might take heed." Therefore, we can see that the word Noor also stands for guidance as well as a warning. The same chapter has set 
some clear set of instructions on various kinds of crimes, their punishments and repentant. Further, the verse contains:

"God is the light (Noor) of the heaven and the earth. His light (noor) may be compared to a niche containing a lamp, the inside a crystal of star-like brilliance ${ }^{x v}$ lit from a blessed olive tree, neither of the East nor of the West. The (luminous) oil is as if ready to burn without even the fire touching upon it. Light upon light (Noor-ala-noor) ${ }^{\mathrm{xvi}}$; God guides to His lights whom he will" (24:35).

In this verse, the existence of Allah is described through the metaphor of Light. Also, light is guidance from God to mankind, “...Indeed, the man from whom God withholds His light (noor) shall find no light at all" (24:40). The above-quoted verses are only a few to mention the use of the word Noor in different contexts in the Quran. However, we can see the word is already enriched with many theosophical significances within the Quran which is free to interpret and have been adopted since then in many languages including vernacular in different contexts and significances.

\section{Noor in (Classical/Sufi) Arabic and Persian Poetry ${ }^{\mathrm{xvii}}$}

After the emergence of Islam Qasida or Madiah ${ }^{\text {xviii }}$ became a prominent literary genre to express love for the Prophet (SM) and Allah. In one of the poems by an unknown poet cited from the Harvard University website of Sufi poetry, notes the love for the Prophet as it starts:

$$
\text { رابّاني سرّ السرور البدور در }
$$

Badril-Budoori Bahril-Buhoori

Sirris-suroori, sirrin-Rabbaani

Moon of moons, sea of seas

The secret of joy, a divine secret

الابصار ضوء الانوار نور الإنور

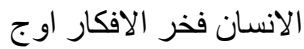

Nuril-anwaari, d̦aw'il-abșaari

Awjil-afkaari, fakhril-insaani

Light of lights, light of sights

The summit of thoughts, the pride of mankind

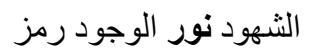

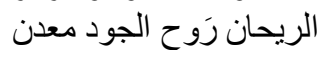

Ramzil wujoodi, nuurish-shuhoodi ${ }^{\text {ix }}$

Ma'dinil-joodi, rawhir-rayhaani

the mystery of existence, the light of witness

treasury of good, the rest of repose

السلام عين بك، أطلب

الختام حسن السلام من الك ابل

Ațlubu bika, 'aynas-salaami,

Min as-Salaami, husnal-khitaami

I seek from you, $\mathrm{O}$ essence of peace

From the Peace, a good end. 
The verse is written in praise of the Prophet describing his appearance and nature using common metaphors around and the word noor or light is one of them:

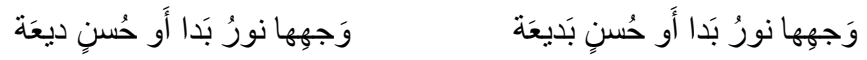

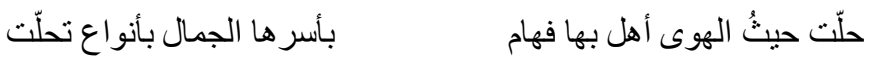

And from my envy, out of the severity of my jealousy

O Dazzling beauty! Should the light of your face

Touch the eyes of a blind man....

....Abu al-Hasan al-Shushtari ${ }^{\mathrm{xx}}$

You look through my two eyes, you are closer to me than myself

Your light shines brighter than the moon

Come into the garden so that the glory of the rose garden is humbled ${ }^{\mathrm{xxi}}$

Jalaluddin Rumi

By the time we come to Rumi in Mysticism, where the word Noor started to be used in an equivocal sense---to refer to the beloved of the poet as well as God.

The travels and adaptation of the word Noor are not limited in the contemporary pop songs as this paper seeks to address. Rather it has come through a long journey both in secular and Islamic religious literature. The usage of this particular word is interesting to note in a few lyrics noted down as below:

What shall I say? Since this saying is fine,

\section{"A bright night in the midst of a dark day"}

In this place of witnessing, which is the light of manifestation

I have much to say, but silence is best.

$$
\text { Mahmoud Shabistari }{ }^{\mathrm{xxii}} \text {, The Rose Garden of Mystery (verses 122-130 }{ }^{\mathrm{xxiii}} \text { ) }
$$

"Should the light of your face

Touch the eyes of a blind man, he would see every atom..."xiv

\section{Al-Shustari ${ }^{\mathrm{xxv}}$}

This is one of the precursors to the naat tradition and the Gazhals which travelled down India to be developed in many languages. In the following verse, the author is unknown although popular, the word Noor is referred time and again to denote the beauty of the Prophet of God, Muhammad (SM). Such kind of writings are abundant in Arabic, Persian, Sindhi, Hindi, Urdu, Bangla in Naat ${ }^{\text {xxvi }}$, Hamd ${ }^{\text {xxvii }}$ and Gazhals. Therefore we can see, in almost all Islamic interpretation the word Noor is associated with deep theological significance and subject to thousands of interpretations. However, the word started travelling to Persian and to Sufi literature where for the first time, the word is used in an equivocal sense---both to denote theological subjects as well as mundane objects. Thus, it would be interesting to see how the word come to be used in contemporary Bollywood and Punjabi pop songs in reference to female beauty and the beloved. 


\section{The Granth Sahib}

After the Quran and the Islamic reception of the word Noor, perhaps the most important usage of the word could be seen in the Granth Sahib, the Holy Book of the Sikhs. In the Granth Sahib, the word appears to be rather a direct adaptation ${ }^{\text {xxviii }}$ from the Arabic:

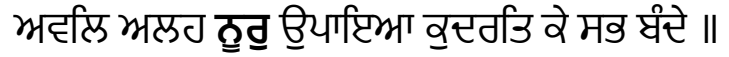

Aval alah nūr upāai

First, Allah created the Light; then, by His Creative Power,

He made all mortal beings.

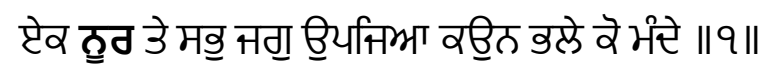

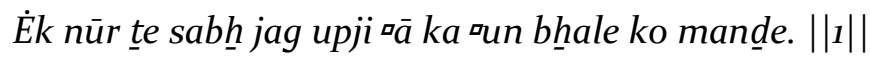

From the One Light, the entire universe welled up.

So who is good, and who is bad? ||1||

The Chapter concludes:

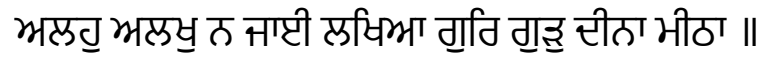

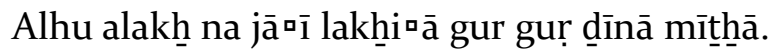

The Lord Allah is Unseen; He cannot be seen.

The Guru has blessed me with this sweet molasses ${ }^{\mathrm{xxix}}$.

(Sri Guru Granth Sahib, Amrit Keertan, p1349).

Appearance and use of the word Noor are perhaps countless in many languages starting from Arabic down to Bangla and other languages in South Asia. However, it should be noted at the outset that Noor the word has not undergone much translation as such, though transliterated in some cases and entered many Bhasha languages in the Indian subcontinent directly and is being used as it is. The following is a lyric from the popular Punjabi song starring Ayushman Khurana, Pani da rang:

Akhiyaan cho anju rul de Maahiya na aaya mera, maahiya na aaya

Ranjhana na aaya mera, maahiya na aaya

Akhaan da noor vekh ke Akhaan da noor vekh ke Akhiyaan cho anju rul de $\mathrm{xxx}^{\mathrm{xx}}$

Which could be translated as:

Seeing the colour of water, tears roll down my eyes my lover didn't come, my beloved didn't come... seeing the glow of the eyes, tears roll down my eyes. ${ }^{\text {xxi }}$

Again in another song:

Kabhi usey noor noor kehta hoon Kabhi main hoor hoor kehta hoon 
7 The Word 'Noor': Tracing a Long Journey through Translation and Adaptation from Classical Arabic to Contemporary Punjabi/Hindi Pop Songs

Ishq mein choor choor rehta hoon

Door naa jaa...

Na ja aankhon aankhon mein hi rehna ${ }^{\mathrm{xxxii}}$

And translated as:

I call her 'beauty' sometimes

I call her an epitome of beauty sometimes

I remain absorbed in love

Don't go away...

Don't go, stay in my eyes ${ }^{\mathrm{xxxiii}}$

The lyrics of these songs are available online in a Hindi and Punjabi mixed language transliterated in English. Again another song reads:

Tu Bada Mashhoor ve, Nira he to Noor ve

Mitha Bada Lagda Ghoor da Saroor ve

Raah Jidde Hon na, Khatam Leja Door ve

Sun Mere Vellia Mein Hoe Majboor ve

Ruk Ruk Saah Chalde, Ishq vich Vadke ${ }^{\mathrm{xxxiv}}$

And in translation:

You are the most sought after, absolute radiance

You are my sweetheart, your gaze delights me

Set me off to endless path, I feel so compelled by love... ${ }^{\mathrm{xxv}}$

Again, in another Punjabi song:

Teri Akhiyan Ch Noor Kinna Sara

Gallan Ch Suqoon Si Sajjna

Teri Akhian Ch Noor Kinna Saara

Gallan Ch Sukoon Si Sajna ${ }^{\text {xxxvi }}$

Translated as:

So much of radiance in your eyes

So much of peace $\mathrm{O}$, love...!

The word Noor has been much been used in religious and secular Qawwalis in different languages. To cite one of the most popular examples from a Qawwali popularly sung by Nusrat Fateh Ali Khan- "Yeh Jo Halka Halka Suroor":

Aisay Rehtay Hein Koi Mere Dil Mein

Jaisay Zulmat Mein Noor Rehta Hai

Ub Adam Ka Yeah Haal Hai Har Waqt

Mast Rehta Hai Chuur Rehta Hai

Could be translated as: 
Someone lives in my heart

Like light in the heart of darkness

Now such is the state of my mind

I remained absorbed in her love all the time...

Again:

Mujhay Bhool Ja'ay Dunya, Mein Agar Tujhe Bhula Doon

Mere Dil Mein Bus Rahe Hein, Tere Bepanah Jalwe

Na Ho Jiss Mein Noor Tera, Woh Charagh Hi Bujha Doon ${ }^{\text {xxxvii }}$

In translation:

If I forget you, the world shall forget me

In my heart dwells, your absolute charisma

If there is no light of yours in the lamp, I shall blow that off too...

And finally, we come to one of the most popular and even evergreen songs in Hindi (although not contemporary yet very popular) sung by Lata Mangeshkar and Kishore Kumar; lyrics penned by Gulzar and RD Burman:

$$
\begin{aligned}
& \text { तुम आ गए हो नूर आ गया है } \\
& \text { तुम आ गए हो नूर आ गया है } \\
& \text { नहीं तो चरागों से लौ जा रही थी } \\
& \text { जीने की तुमसे वजह मिल गयी है } \\
& \text { बड़ी बेवजह जिन्दगी जा रही थी } \\
& \text { तुम आ गए हो नूर आ गया हैxxxviii }
\end{aligned}
$$

Translated as:

You have arrived so the light has also come.

Otherwise, even the light was going off the lamp.

You've given me a reason to live

As I was living a purposeless life

You have arrived so the light has also come.

\section{Conclusion}

Thus we can see the translation and adaptation of the word Noor is both a conscious and spontaneous act used in different contexts we have seen in the cited lyrics and texts from across languages and cultures. Here the word itself is not 'recontextualised' as Venuti proposed in his book, rather the significances and importance of the word are 'recontextualised'. The travel of the word Noor is not only an act of translation/adaptation but linguistic too. However, more than the linguistic side, this paper focused on exploring the significance of the word and its changes in translation studies. Further, 'translation is a never-ending process, it shall go on as long as man continues to live'. In reference to this particular assumption of George Steiner, we can also say that the word Noor continues to be adopted and used in different ways and different sources which may 
sometimes appear surprising, perhaps astonishing if it is seen how it was used in Islamic and secular literature and its modern and contemporary usages. More than anything else the word itself has become part of the vocabulary in many Asian and European languages and it is understood without translation, including English. In this particular case, we can see an interesting case of translation, transliteration and adaptation of a word in a curious way which deserves further attention from the scholars of language and cultural studies and translation studies.

\section{Notes}

i Although originated and transferred from Arabic the word Noor in the Indian context is a part of many vernacular languages. Therefore introducing the word Noor as an Arabic word could be problematic.

ii <<https://en.wiktionary.org/wiki/\%D9\%86\%D9\%88\%D8\%Bi\#Arabic >> The given Arabic transliteration is free to write in Aramaic and Hebrew too, since Proto-sematic is a hypothetically constructed language, it does not have any particular script as such.

iii This paper shall begin by stating the limitation or opportunities of this prospect in this way. The whole concept of Noor and its reception and appropriation in various languages should be understood in a paper written in the English language presented here in Patna. What is important here is 'understanding 'as George Steiner would put in his book After Babel (1976)---the journey of the word and the significance of it through translation and re-translation into English in this paper. Thus, a language cannot be a barrier to understand the journey of a word from Arabic to modern Bhasha languages.

iv One may certainly disagree with this argument. The words like humsafr, safr and others too, needs to be investigated in details and maybe compared with the word Noor to reach a mutual argument. Considering the limitation of scope and space, this paper leaves that open to the readers or with a promise of sequence papers.

${ }^{v}$ https://biblehub.com/hebrew/5135.htm

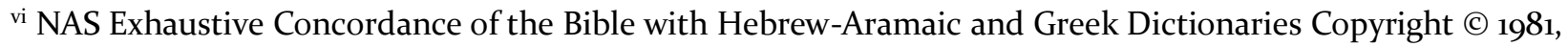
1998 by The Lockman Foundation All rights reserved Lockman.org

vii Some words are highlighted and in bold in order to attract the attention of the readers who are not familiar properly with languages mentioned here

viii Ibid.

ix This particular word is a part of Classical Syriac Aramaic version of a branch of Aramaic languages, as there were several dialects/versions of Aramaic language. Notably the Galilean dialect of Aramaic language was the language of Jesus.

x The Greek word here is 'phoes' which is of course, a translation from Hebrew and Aramaic, the KJV is a not a direct translation from Hebrew or Aramaic

xi The scope of the word Noor in different medium of art is huge and it will take perhaps a $\mathrm{PhD}$ theses to access usage of the word stating from sacred texts, literature, painting and in modern world languages. This paper is just an attempt to address one the fields i.e., contemporary and popular Punjabi and Bollywood songs.

xii The "/" could be taken as "and" too

xiii Shulamit Binah. “Arabic is still Hebrew's sister language”. Times of Israel, September 11, 2018 UTC o7:12 PM. Last accessed from New Delhi on 30.03.2020 at 04:44 PM. 
xiv This sentence may not be necessary here yet added for the readers who are not familiar with Middle Eastern languages and culture in depth

${ }^{x v}$ My emphasis

${ }^{\text {xvi }}$ My parenthesis

xvii Scope and opportunity of the word is huge. From pre-Islamic to Islamic literatures in all the languages, Sufi literatures, secular literatures, paintings etc. in Arabic and Persian, the impact of the word Noor is enormous, perhaps this will take a whole $\mathrm{PhD}$ thesis to map that down. In order to keep that paper within its limits it merges Arabic Persian and Sufi literatures in one section, however, this is just the beginning.

xviii A form of writing poetry in praise of a patron. This tradition even dates back to pre-Islamic Arabic

${ }^{\text {xix }}$ Known as Mawlids, written to celebrate the birth anniversary of the Prophet (SM)

${ }^{x x}$ https://blogs.harvard.edu/sulaymanibnqiddees/tag/arabic-sufi-poetry/

xxi Ibid.

xxii $1288-1340$, one of the most celebrated poets in Persian in $14^{\text {th }}$ century

xxiii Ibid

xxiv Ibid

${ }^{x x v}$ Abu-al-Hasan ibn Abdullah Al-Sushtati (1212-1269) was an Andalusian Sufi poet writing in Arabic

xxvi Verses (to be sung with and without musical instruments) in praise of Prophet Muhammad (SM)

xxvii Verses (to be sung with and without musical instruments) in praise of Allah and His greatness

xxviii And this adaptation perhaps is a normal process of incorporating Arabic-Persian-Turkish words in Indian apabhramsha languages with the advent of Islam in the Indian subcontinent

xxix http://www.srigranth.org/servlet/gurbani.gurbani?Action=KeertanPage\&K=1349\&L=19

xxx Understanding the limitation of the paper this paper avoids citing full lyrics of the cited texts/songs. However they could be accessed anytime with just a simple google search though links are provided in the footnotes and Works Cited sections.

xxxi Movie: Vicky Donor

Music:Rochak Kohli with Ayushmann Khurana

Singer: Ayushmann Khurana

Translation: http://www.bollymeaning.com/2012/o4/paani-da-range-vekh-ke-lyrics.html

xxxii Music Composer: Shankar Ehsaan Loy

Lyrics Writer: Gulzar

Singers: Diljit Dosanjh

Director: Shaad Ali

Movide/Album Name: Soorma (2018)

xxxiii My translation

xxxiv Album: Single Track 2019

Singer: Jassa Dhillon

Song and Lyrics: Pyar Bolda

Music: Gur Sindhu 
xxxv Helped in translation by Gurpreet Kaur, Assistant Professor, Department of English Mata Sundari College, Delhi University.

xxxvi Song: Awaaz (2018)

Album/Movie: Qismat

Singer: Kamal Khan

Lyrics: Jaani

Director: Jagdeep Sandhu

xxxvii Originally written by his brother, Ali Fateh Khan Farrukh

xxxviii Movie: Andhi (1975)

Song by: Lata Mangeshkar and Kishore Kumar

Music Composer: RD Burman

Lyrics: Gulzar/RD Burman

\section{References}

Bassnett, Susan. (2002). Translation Studies. New York: Routledge.

Lefevere, Andre. (1975). Translating Poetry: Seven Strategies and a Blueprint. Amsterdam.

Lefevere, Andre (Ed.). (1993). Translation/History/Culture. New York: Routledge.

Steiner, George. (1975 rep. 2013). After Babel: Aspects of Language and Translation. Newburyport: Open Road Media.

Venuti, Lawrece. (2013). Translation Changes Everything: Theory and Practice. Oxon: Routledge.

Binah, Shulamit. September 11, 2018 UTC 07:12 PM. “Arabic is still Hebrew's sister language”. Times of Israel. Digital.

Harvard Blog for Sufi Poetry. https://blogs.harvard.edu/sulaymanibnqiddees/tag/persian-sufi-poetry/

Urban Dictionary. https://www.urbandictionary.com/define.php?term=Noor

Lyrics in Translation. https://lyricstranslate.comhttps://lyricstranslate.com

Bollywood Meaning. http://www.bollymeaning.com/2012/o4/paani-da-range-vekh-ke-lyrics.html

Sri Guru Granth Sahib.

http://www.srigranth.org/servlet/gurbani.gurbani?Action=KeertanPage\&K=1349\&L=19

Wiki Dictionary. https://en.wiktionary.org/wiki/\%D9\%86\%D9\%88\%D8\%Bı\#Arabic

The Bible Hub. https://biblehub.com/hebrew/5135.htm 